\title{
Chemical composition, fermentation, in vitro digestibility and in situ degradability of sugar cane silages with Lactobacillus, urea and agricultural byproduct
}

\section{Emilyn Midori Maeda ${ }^{1,4}$, Lucia Maria Zeoula ${ }^{2,5}$, Clóves Cabreira Jobim²,5, Franciele Bertaglia ${ }^{3}$, Roberto Cornelis Jonker ${ }^{3}$, Luiz Juliano Valério Geron ${ }^{1}$, Douglas Sampaio Henrique ${ }^{4}$}

\footnotetext{
1 Programa de Pós-Graduação em Zootecnia - UEM, Maringá-PR.

2 Departamento de Zootecnia - UEM, Maringá-PR.

${ }^{3}$ Curso de Graduação em Zootecnia - UEM, Maringá-PR. Scholar from PIBIC.

${ }^{4}$ Universidade Tecnológica Federal do Paraná/UTFPR, Dois Vizinhos-PR.

${ }^{5}$ Researcher from CNPq.
}

ABSTRACT - The objective of this study was to evaluate the sugarcane silage in relation to chemical composition, $\mathrm{pH}$, total losses, aerobic stability, in vitro digestibility of dry matter (IVDDM) and effective degradability (ED) of bovine and buffaloes under the following treatments (on a dry matter (DM) basis): sugarcane silage control (control), with addition of $3.3 \%$ urea; with addition of Lactobacillus buchneri (inoculate); with inoculate $+3.3 \%$ urea; with inoculate $+25.0 \%$ soybean hull, and with inoculate $+25.0 \%$ cassava byproduct meal. The experiment was analyzed through a completely randomized design with three replications, and for DM ED, a double $4 \times 4$ Latin square with a $4 \times 2$ factorial arrangement was used. The sugarcane variety was the RB-855156 (precocious). The urea increased the protein level and reduced neutral and acid detergent fiber and lignin fractions. Treatments with inoculate + cassava byproduct and inoculate + soybean hull increased DM levels. Bovines presented higher IVDDM than buffaloes. pH values varied from 3.1 to 4.0. Mean total losses observed were $7.8 \%$. Treatments with inoculate + cassava and inoculate + soybean hulls resulted in larger aerobic stability with 61 and 81 hours, respectively, in relation to silages control (24 h) and control with 3.3\% urea (33 h). A higher DM ED was verified for silages with inoculate + control and inoculate + soybean hulls at $2 \% / \mathrm{h}$ passage rates and higher neutral detergent fiber ED for the treatment of control + inoculate + soybean hulls at 2 and 5\%/h. Silages treated with urea, L. buchneri or agricultural byproduct plus inoculate presented better quality pattern.

Key Words: bovine, buffaloes, cassava byproduct meal, Lactobacillus buchneri, soybean hulls

\section{Introduction}

Cattle rearing in Brazil is traditionally performed with pastures as food source for bovines, which is a practical and economical way. During the dry season, in which the forage production is qualitatively and quantitatively insufficient, the sugar cane becomes an alternative as a roughage supplement (Fernandes et al., 2003). Due to its high production, sugar cane is outstanding among the forage grasses - with production varying from 60 to 120 fresh integral tons/ha - in addition to its ability to maintain the energy potential during the dry season (Thiago \& Vieira, 2006).

The sugar cane ensilage results in the organizational facility and in the reduction of the labor due to the concentration of the activities and to the time of the best nutritional value of the forage (Nussio \& Schmidt, 2004; Siqueira et al., 2010). However, the sugar cane ensilage causes alcoholic fermentation due to high levels of soluble carbohydrates, since the biochemical fermentation pathway of the yeast forms two molecules of ethanol from one molecule of glucose (McDonald et al., 1991).

The major problem in the sugar cane ensilage process is due to the loss fermentation processes. Thus, the use of additives is essential for inhibiting the proliferation of the fungi, yeast and ethanol production. Several additives, such as the heterofermentative lactic acid bacterium Lactobacillus buchneri and/or chemical additives have been studied for reduction of these losses (Mendes et al., 2008; Ribeiro et al., 2010).

The sugar cane shows limitation with regard to the nutritional aspect, since it presents low levels of crude protein; however, the addition of urea may mitigate this nutritive deficiency. Moreover, the addition of sources of carbohydrates such as soybean hulls and cassava byproduct may reduce the production of the effluents and increase the silage nutritive value.

In this way, the objective of the present study was the evaluation of the associative effect of microbial and nutritional 
additives upon the chemical composition, in vitro digestibility of $\mathrm{DM}, \mathrm{pH}$, aerobic stability and in situ degradability of DM, and NDF of sugar cane silages.

\section{Material and Methods}

The experiment was developed at the Fazenda Experimental de Iguatemi (FEI) (Experimental Farm of Iguatemi) and the chemical analyses were processed at the Laboratório de Análises de Alimentos e Nutrição Animal (Laboratory of Analyses of Food and Animal Nutrition), which belong to the Departamento de Zootecnia of the Universidade Estadual de Maringá, Parana state, Brazil.

The harvest and ensilage of the sugar cane was carried from 10 to 13 of July 2005. The variety of sugar cane used was RB 855156 (precocious), harvested in the $11^{\text {th }}$ month first cut - with estimated production of 94 tons/ha of fresh forage, mean value of $17.9^{\circ}$ Brix, and supplied by COOPERVAL - Cooperativa Agroindustrial Vale do Ivaí Ltda (Ivaí Valley Agroindustrial Cooperative Ltd), in the municipality of Jandaia do Sul, Parana State, Brazil, and was transported to FEI for the silage confections.

For the evaluations of $\mathrm{pH}$, total losses, aerobic stability, and in vitro digestibility of dry matter (DM) with ruminal liquid from bovine and buffaloes, the silages were confectioned in laboratorial silos made of PVC (50 cm high and with diameter of $20 \mathrm{~cm}$ ).

For each treatment presented next, three silos were used as repetitions:

a) Silage of sugar cane (control);

b) Silage of sugar cane with addition of urea;

c) Silage of sugar cane with addition of bacterial inoculate;

d) Silage of sugar cane with addition of bacterial inoculate and urea; e) Silage of sugar cane with addition of bacterial inoculate and cassava byproduct;

f) Silage of sugar cane with addition of bacterial inoculate and soybean hulls.

For the evaluation of the DM and NDF ruminal degradability and for the assay of total and partial digestibility carried concomitantly,approximately $7,000 \mathrm{~kg}$ of silage of sugar cane (control); control + inoculate + cassava byproduct; control + inoculate + soybean hulls and control + inoculate + urea were confectioned in trench silos (Table 1).

The additives were applied to chopped sugar cane before filling the silos, distributing the mass uniformly. The bacterial inoculate containing heterolactic bacteria (Lactobacillus buchneri) NCIMB 40788, dose of $5 \times 10^{4} \mathrm{ufc} / \mathrm{g}$ was administered as aqueous solution using manual pulverizer with distilled water according to the manufacturer's guidelines.

The urea (33 g/kg DM) was used as granules containing $45 \%$ of nitrogen, applied manually and in bulks on the chopped forage during the silo filling to improve the protein level and activity of microorganisms and also the cell wall of the silage (Lima et al., 2002; Molina et al., 2002).

The soybean hulls, presenting a high level of digestible fiber and high level of pectin, and the cassava byproduct, with high level of starch, were homogenized to the chopped sugar cane in the proportion of $250 \mathrm{~g} / \mathrm{kg} \mathrm{DM}$ (Freitas et al., 2006).

The sugar cane without removal of straws was processed in a forage stationary chopper adjusted for cuts with mean sizes of $10 \mathrm{~mm}$. At the laboratorial silos, the ensilage was carried out compacting 5-10 cm layer of sugar cane with wood stake to reach the maximum compaction. Approximately $10 \mathrm{~kg}$ of forages were ensiled in laboratorial silos made of PVC resulting in a specific mass of $600 \mathrm{~kg} / \mathrm{m}^{3}$. After filling, silos were covered with double plastic canvas,

Table 1 - Chemical composition of feeds and enriched silages produced in trench silos (g/kg DM) ${ }^{1}$

\begin{tabular}{|c|c|c|c|c|c|c|c|}
\hline Variable & SC & СРM & $\mathrm{SH}$ & SCSI & SCSIC & SCSIS & SCSIU \\
\hline OM & 968.6 & 991.2 & 957.3 & 951.6 & 955.6 & 956.5 & 946.7 \\
\hline Ash & 31.4 & 08.8 & 42.7 & 48.4 & 44.4 & 45.4 & 53.3 \\
\hline NDF & 501.3 & 70.9 & 704.6 & 611.0 & 490.1 & 593.7 & 631.3 \\
\hline $\mathrm{ADF}$ & 314.0 & 41.1 & 554.1 & 424.3 & 326.3 & 426.4 & 404.9 \\
\hline LIG & 70.0 & 16.1 & 56.0 & 89.4 & 57.8 & 62.8 & 89.0 \\
\hline NDIN $^{2}$ & 339.3 & 172.6 & 413.4 & 349.9 & 283.8 & 315.1 & 119.2 \\
\hline $\mathrm{ADIN}^{2}$ & 326.9 & 54.7 & 143.9 & 345.7 & 245.6 & 202.6 & 100.0 \\
\hline Silica & - & - & - & 30.8 & 23.2 & 16.2 & 32.5 \\
\hline
\end{tabular}

${ }^{1}$ SC = sugar cane; CPM = cassava byproduct meal; SH = soybean hulls; SCSI = sugar cane silage + inoculate; SCSIC = SCSI + cassava by product meal; SCSIS = SCSI + soybean hulls; SCSIU $=$ SCSI + urea

2 NDIN = neutral detergent insoluble nitrogen; ADIN = acid detergent insoluble nitrogen (\% total $\mathrm{N})$. 
sealed with self-adhesive plastic tape to avoid the entrance of air, for further weighing and storing.

In the trench silos without covering, the soil was covered with bagasse and the laterals, with plastic canvas. The application of additives was done directly on the chopped sugar cane, compacting it with a tractor. After the silo filling, it was covered with plastic canvas protected with bagasse.

To evaluate the in vitro digestibility of the DM (IVDDM) of the silage confectioned in laboratorial silos, ruminal liquid of a crossbreed bubaline and a Holland bovine cannulated was used in the rumen with body weight of 340 and $420 \mathrm{~kg}$, respectively. They were fed silage of sugar cane with addition of bacterial inoculate and cassava byproduct roughage and concentrate based on soybean meal and ground corn in the proportion of 50:50\% roughage:concentrate.

To evaluate the ruminal degradability of DM and NDF of the sugar cane silages (control + inoculate; control + inoculate + cassava byproduct; control + inoculate + soybean hull and control + inoculate + urea), four male castrated Holland bovines and four male castrated crossbred bubaline, with mean body weight of $492 \pm 10 \mathrm{~kg}$, and $403 \pm 49 \mathrm{~kg}$, respectively, (all fistulated in the rumen) were used. The diet was comprised of ground corn, soybean meal, and sugar cane silage in a relation of 60:40 roughage:concentrate. The diets were balanced to be isonitrogenous and isoenergetic ( $12 \%$ of $\mathrm{CP}$ and $69 \%$ of TDN) according to the NRC (1996), and offered ad libitum. Animals were adapted to the diets during 10 days and placed in individual stalls covered with troughs (to eat and to drink).

After 110 days, the laboratorial silos were weighted and opened for sampling and each silage sample was comprised of three subsamples taken from the central part of each silo (Table 2).

The samples for the $\mathrm{pH}$ determination were placed in plastic bags and stored $\left(-10^{\circ} \mathrm{C}\right)$ for further analysis. Samples were defrosted and the $\mathrm{pH}$ was measured in the moment right after the extraction of the juice with hydraulic press, using a digital potentiometer.

For evaluation of total losses, the laboratorial silos were weighted empty, after the filling, and at the end of the ensilage period (Jobim et al, 2007).

The aerobic stability of the silages (expressed in hours) was evaluated through the temperature control of the silage exposed to the air, according to the adapted method of Kung Jr et al. (2000). The silages of each treatment were kept in sheltered environment, without temperature control. The temperatures were measured three times along the day (09:00 AM, 01:00 PM, and 05:00 PM) using a thermometer
(Gulterm ${ }^{\circledR}$ ) positioned at the geometric center of the forage mass of each silo. The beginning of the deterioration when the temperature of the silages reached $2{ }^{\circ} \mathrm{C}$ above the room temperature was taken into consideration.

The IVDDM of the sugar cane silages was determined according to the one-stage methodology of Baumgardt et al. (1962).

In addition to the test tubes containing the silage samples (six treatments), the control (white) and index forages were incubated to evaluate the effect of any interference that might happen during the incubation period. All the samples, control and forage were incubated in triplicate. A total of 162 incubations were done, containing samples of silage per animal [6 treatments $\times 3$ repetitions (silo) $\times 3$ days of sampling of the ruminal liquid $\times 3$ tubes $]$.

The degradability of the DM and NDF was estimated by the in situ technique of the nylon bag. Approximately $6 \mathrm{~g}$ of the samples dried in open air $\left(20 \mathrm{mg} \mathrm{MS} / \mathrm{cm}^{2}\right)$, with particle size of $5 \mathrm{~mm}$, were placed in bags of mono-filament polyester, sealed by heat made in nylon (ANKON-BAR DIAMOND, INC., Parma Idaho - USA). The bags dimension was $10 \times 20 \mathrm{~cm}$, with pore diameter of $53 \mathrm{~mm}$. Bags were weighted, then closed and attached in triplicate per sample/ times to a 600 -g stainless steel cylindrical tank, hanged by a $60-\mathrm{cm}$ nylon string to the ruminal fistula.

The incubation times were employed as zero, $6,12,18$, 24, 48, 72, 96, and 144 hours. Bags containing samples of silage of sugar cane with addition of inoculate, with inoculate + cassava, inoculate + soybean hulls and with inoculate + urea were incubated in the animals in two Latin squares ( 4 bovines and 4 buffaloes) that received the corresponding treatment.

After the removal, bags were washed in running water and washing machine in 5 cycles per minute. The bags with the samples of the time zero hour were placed in water bath at $39^{\circ} \mathrm{C}$ during 30 minutes, and then washed.

After the washing, bags were submitted to drying in forced ventilation oven at $55{ }^{\circ} \mathrm{C}$ during 72 hours and ground in ball mill for 10 second at most. The percentages of DM and NDF disappearances, in function to the time of incubation, were calculated through the proportion of food that remained in the bags after the ruminal incubation.

The degradation profile of DM was interpreted through the model described by Mehrez \& Orskov (1977): $p=a+b$ $\left(1-\mathrm{e}^{-\mathrm{ct}}\right)$, where: $\mathrm{p}=$ degraded fraction of $\mathrm{DM}$ at incubation time $\mathrm{t}(\mathrm{g} / 100 \mathrm{~g})$; $\mathrm{a}=$ soluble fraction of DM (g/100 g); b = insoluble but potentially degradable fraction of $\mathrm{DM}(\mathrm{g} / 100 \mathrm{~g})$; $\mathrm{c}=$ fractional degradation rate of fraction $\mathrm{b}(\mathrm{h})$; and $\mathrm{t}=$ incubation time. 
Parameter estimates of NDF degradation were determined from the model proposed by Van Milgen et al. (1991): R $\left(\mathrm{t}_{\mathrm{i}}\right)=\mathrm{U}\left[\mathrm{c} \exp \left(-\mathrm{pt}_{\mathrm{i}}\right)-\mathrm{p} \exp \left(-\mathrm{ct} \mathrm{t}_{\mathrm{i}}\right) / \mathrm{c}-\mathrm{p}\right]+\mathrm{I}+\mathrm{e}_{\mathrm{i}}$; where: $\mathrm{R}\left(\mathrm{t}_{\mathrm{i}}\right)$, $\left(\mathrm{g} \mathrm{kg}^{-1} \mathrm{DM}\right)$ is the incubation residue, after a given time; $t_{i}(h)$; $U$, ( $g^{-1} \mathrm{DM}$ ) is equivalent insoluble but potentially degradable fraction non available for digestion until the end of the latency period, where, gradually, the ratio $\mathrm{p}\left(\mathrm{h}^{-1}\right)$ becomes available; the fraction $\mathrm{U}$ is available to be called A, the rate of digestion is described by $c\left(\mathrm{~h}^{-1}\right)$; and I ( $\mathrm{g} \mathrm{kg}^{-1} \mathrm{DM}$ ) represents the undegradable fraction, with no changes as a time function for microbial action, i.e., when $t_{i} \rightarrow \infty$; is the error. When $p$ tended to $c$, the rule of L'Hôpital was applied for obtainment of the equation described by Van Milgen et al (1991): $\mathrm{R}\left(\mathrm{t}_{\mathrm{i}}\right)=\mathrm{U}\left(1+\lambda \mathrm{t}_{\mathrm{i}}\right) \exp$ $\left(-\lambda \mathrm{t}_{\mathrm{i}}\right)+\mathrm{I}+\mathrm{e}_{\mathrm{i}}$; where $\lambda$ represents degradation rate $\left(\mathrm{h}^{-1}\right)$ when $p$ tends to $c$.

The non-linear parameters ( $\mathrm{a}, \mathrm{b}, c, \lambda$ and $p$ ) were estimated through the iterative least-squares in SAS (1997) by the Marquard algorithm method.

The effective degradability (ED) of DM in the rumen was calculated through the equation described by Orskov \& McDonald (1979): Effective degradability $=a+(b c / c+k)$ and ED of NDF were estimated using equations described by Vieira et al. (1997):

$$
E D=C F d \frac{c p}{(c+k)(p+k)}
$$

And when $p$ tended to $c$ (Vieira et al., 1997):

$$
E D=N D F p \frac{\lambda^{2}}{\left(\lambda^{2}+K\right)^{2}}
$$

where: $\mathrm{CFd}=\mathrm{U} /(\mathrm{U}+\mathrm{I}) \times \mathrm{NDF}_{\mathrm{p}} ; \mathrm{k}=$ estimated rate of passage of the solids in the rumen; the other parameters were described in the previous equation.

The effective degradability of DM and NDF were estimated for each food, for which the rates of passage of the solids of $0.02 / \mathrm{h}$ and $0.05 / \mathrm{h}$ that are attributed, respectively, to the low and medium levels of food intake (AFRC, 1993).

All the samples were dried in oven with artificial ventilation at $55^{\circ} \mathrm{C}$ during $72 \mathrm{~h}$ and for the chemical analyses they were ground in knife mill with 1-mm sieve and stored in plastic flasks.

Contents of DM, Ash, ether extract (EE) and crude protein (CP) were determined according to AOAC (1980) cited in Silva \& Queiroz (2002). The determinations of the neutral detergent fiber (NDF) and acid detergent fiber (ADF) were performed according to Van Soest et al. (1991); from the residuals from the NDF and ADF, the neutral detergent insoluble nitrogen (NDIN), and the acid detergent insoluble nitrogen (ADIN) were analysed, according to Licitra et al. (1996). The lignin was determined in the samples according to Van Soest \& Wine (1968) and the silica according to Van Soest \& Jones (1968). For the quantification of the total carbohydrates (TC), the following equation was used: 100 - (\% CP + \% EE + \% ashes) and the level of non-fibrous carbohydrates (NFC) was obtained by the difference between the levels of TC and $\mathrm{NDF}_{\mathrm{P}}$, in which $\mathrm{NDF}_{\mathrm{P}}$ comprises the vegetal wall free of crude protein (Sniffen et al., 1992). The levels of the samples of the foods and residuals of the bags from the in situ degradability assay were analysed through the fiber analyser equipment Ankon ${ }^{\circledR}$, using F57 (Ankon ${ }^{\circledR}$ ) bags.

The experimental design used in the evaluation of the chemical compositions, IVDDM, pH, and total losses of the sugar cane silages of the laboratorial silos was completely randomized, with three repetitions per treatment (six treatments). With regard to the in situ degradability of DM, two $4 \times 4$ Latin squares and $4 \times 2$ factorial arrangement (four diets and two species) were used; one species in each Latin square. The statistic analyses of the studied variables were interpreted in the Sistema de Análises Estatísticas e Genéticas (SAEG) through the variance analyses (UFV, 1997), and the means were compared using the test of Tukey at $5 \%$ significance.

\section{Results an Discussion}

The addition of urea to the sugar cane silage without the bacterial inoculate elevated the protein level of the roughage and reduced the DM and the NDF, ADF, lignin, NDIN and ADIN levels $(\mathrm{P}<0.05)$. These results corroborate with Lima et al. (2002), who reported that sugar cane silages treated with levels between 5 and $15 \mathrm{~g} / \mathrm{kg}$ of urea would offer good pattern of fermentation and better chemical composition as higher levels of DM and lower levels of ADF and NDF in comparison with the sugar cane silage, exclusively. The use of urea in the sugar cane ensilage concentrated the DM level; however, there was increase in hemicellulose solubility (NDF minus ADF) in relation to control (Table 2).

Nevertheless, the additions of L. buchneri and urea to the sugar cane silage reduced the level of DM and increased $(\mathrm{P}<0.05)$ the NDF and lignin fractions in relation to the addition of urea solely. Thus, it was observed that the associative effect reduced the quality of the sugar cane silage with urea. Moreover, in the in vivo digestibility assay carried in parallel to this study, there was reduction in the total digestibility of DM and nutrients to bovines 
and buffaloes fed on sugar cane silage and addition of L. buchneri and urea in relation to the control and the other treatments - with addition of inoculate + cassava byproduct and inoculate + soybean hulls (Maeda, 2007). Greater ammonia and alcoholic odor in the silage was also observed with the addition of inoculate and urea, suggesting greater action of yeast population. Possibly, the ammonia formed by the action of urease on urea minimized the effect of $L$. buchneri in reducing population yeast.

Variations in the levels of NDF and ADF were noticed among the sugar cane silages in function of the additives employed. The addition of bacterial inoculate diminished the levels of NDF and ADF in relation to control, and the addition of cassava byproduct reflected in lower level of $\operatorname{NDF}(\mathrm{P}<0.05)$ in relation to the silage with inoculate only a result of lower levels of NDF and ADF in the cassava byproduct meal. On the other hand, when the soybean hull was added to the sugar cane silage, the levels of NDF (silage with inoculate + soybean hull) did not show difference in comparison with control and control + inoculate due to the high values of NDF of the residuals $-705.0 \mathrm{~g} / \mathrm{kg}$ (Table 1). According to Rotz \& Muck (1994), the variations in the levels of NDF and ADF (\% DM) in silages are dependent on the losses through respiration in relation to the amount of hydrolyzed cell wall or as consequence of the loss of other non-structural carbohydrate. Loss of soluble carbohydrates during fermentation and concentration of fibrous components are also observed in the ensiling process of sugar cane (Pedroso et al., 2005; Mendes et al., 2008), which may also have occurred in this study.

The low concentration of lignin $(\mathrm{P}<0.05)$ in the sugar cane silages with urea and with byproducts (control with inoculate + soybean hulls and inoculate + cassava byproduct) is outstanding, besides the high levels of ADIN in the sugar cane silage (control) (Table 1).

No interaction of treatments or animal species $(\mathrm{P}>0.05)$ were observed for the in vitro digestibility of the DM (IVDDM) of the sugar cane silages treated with different additives; however, there was an effect $(\mathrm{P}<0.05)$ for the treatments and for the species (Table 3 ).

Thus, regardless of the inoculate used in the rumen, of either bovine or bubaline, treatments with inoculate + cassava byproduct; inoculate + soybean hull; or with sole addition of urea did not present any difference and were superior $(\mathrm{P}<0.05)$ to the silages of sugar cane and with sole addition of $L$. buchneri. The addition of urea associated to the inoculate presented an intermediary value of IVDDM (449 g/kg), not differing from the other treatments. The results of in vitro digestibility corroborated, mostly, with the results regarding the in vivo digestibility in an assay carried concomitantly, since regardless of the animal species, there was higher value of total digestibility of DM for silage with inoculate + soybean hull $(612 \mathrm{~g} / \mathrm{kg})$, followed by silage with inoculate only (558 g/kg) and inoculate + cassava

Table 2 - Chemical composition of sugar cane silages (g/kg dry matter) made in laboratorial silos

\begin{tabular}{|c|c|c|c|c|c|c|c|c|}
\hline Feeds $^{1}$ & $\mathrm{DM}$ & CP & NDF & ADF & LIG & ASH & NDIN $^{2}$ & $\mathrm{ADIN}^{2}$ \\
\hline SCS & $272.0 c$ & $23.3 \mathrm{~b}$ & $585.0 \mathrm{a}$ & $364.7 \mathrm{a}$ & $72.9 a$ & $45.1 \mathrm{a}$ & $418.2 \mathrm{a}$ & $346.1 \mathrm{a}$ \\
\hline SCSU & $314.4 \mathrm{ab}$ & $95.9 a$ & 489.1c & 309.6b & $51.0 \mathrm{bc}$ & $39.1 \mathrm{ab}$ & $83.2 b$ & $52.2 d$ \\
\hline SCSI & $281.2 b c$ & $29.2 b$ & $516.1 \mathrm{bc}$ & $330.3 b$ & $66.7 \mathrm{a}$ & $38.0 \mathrm{ab}$ & $367.5 a$ & $302.0 \mathrm{ab}$ \\
\hline SCSIU & $263.3 c$ & $101.7 \mathrm{a}$ & $566.0 \mathrm{ab}$ & $346.4 \mathrm{ab}$ & $65.2 \mathrm{ab}$ & $47.1 \mathrm{a}$ & $161.2 b$ & $62.5 \mathrm{~d}$ \\
\hline SCSIC & $335.2 \mathrm{a}$ & $18.7 \mathrm{~b}$ & $387.9 d$ & 237.3c & $44.4 \mathrm{c}$ & $33.5 b$ & $362.9 \mathrm{a}$ & $278.1 \mathrm{~b}$ \\
\hline SCSIS & $322.8 \mathrm{a}$ & $47.0 \mathrm{~b}$ & 545.7abc & 391.6a & $47.1 \mathrm{c}$ & $47.2 \mathrm{a}$ & $375.7 \mathrm{a}$ & $179.5 c$ \\
\hline CV (\%) & 4.72 & 22.88 & 4.28 & 5.04 & 8.64 & 8.26 & 16.87 & 12.09 \\
\hline
\end{tabular}

${ }^{1}$ Sugar cane silage (SCS), SCS + urea (SCSU), SCS + inoculate (SCSI), SCSI + urea (SCSIU), SCSI + cassava byproduct meal (SCSIC), SCSI + soybean hulls (SCSIS).

$2 \%$ total $\mathrm{N}$.

Means followed by different letters, within a column differ $(\mathrm{P}<0.05)$ by Tukey test. CV = coefficient of variation.

Table 3 - In vitro dry matter digestibility (IVDDM), $\mathrm{pH}$ and total losses (TL) of sugar cane silages with different additives ${ }^{1}$

\begin{tabular}{|c|c|c|c|c|c|c|c|}
\hline & \multicolumn{7}{|c|}{ Treatment $^{1}$} \\
\hline & SCS & SCSU & SCSI & SCSIU & SCSIC & SCSIS & CV (\%) \\
\hline IVDDM $\mathrm{g} / \mathrm{g}$ & $0.402 b$ & $0.522 \mathrm{a}$ & $0.413 b$ & $0.449 a b$ & $0.543 a$ & $0.534 \mathrm{a}$ & 10.35 \\
\hline $\mathrm{pH}$ & $3.3 d$ & $3.7 b$ & $3.1 \mathrm{~d}$ & $4.0 \mathrm{a}$ & $3.2 \mathrm{~d}$ & $3.5 c$ & 2.02 \\
\hline $\mathrm{TL}$ g/kg & 81 & 74 & 76 & 84 & 79 & 71 & 15.15 \\
\hline
\end{tabular}

Species

\footnotetext{
${ }^{1}$ Sugar cane silage (SCS), sugar cane silage + urea (SCSU), sugar cane silage + inoculate (SCSI), SCSI + urea (SCSIU), SCSI + cassava by product meal (SCSIC), SCSI + soybean hulls (SCSIS).

Different small letters in the same row compared means between experimental diets, and capital letters at same row compared means between species ( $<0.05)$. $\mathrm{CV}=$ coefficient of variation.
} 
byproduct $(554 \mathrm{~g} / \mathrm{kg})$ that were superior $(\mathrm{P}<0.05)$ to the associative effect of the inoculate and the urea $(501 \mathrm{~g} / \mathrm{kg})$ (Maeda, 2007).

The increases of IVDDM found when adding the byproducts to the sugar cane silage with addition of $L$. buchneri are due to the nutritional value of the soybean hull - with the low level of lignin and NDF of high ruminal digestibility (Zambom et al., 2001) - and cassava byproduct meal - with high level of starch and low levels of NDF and ADF (Zeoula \& Caldas Neto, 2001). Moreover, the increase of the levels of DM combined with the effect of L. buchneri reduced the losses of soluble carbohydrate during the fermentation process, which may have taken a higher speed acidification, fastest $\mathrm{pH}$ fall, with consequent redutions in losses and the low concentration of lignin found in these treatments (44; 47 vs. $67 \mathrm{~g} / \mathrm{kg}$ ) may explain such results.

Similarly, Freitas et al. (2006) reported for the sugar cane silage treated with bacterial inoculate and sdium hydroxide plus residual of the soybean harvest, higher value of IVDDM $(0.705 \mathrm{~g} / \mathrm{g})$ in relation to the non-addition of residual $(0.587 \mathrm{~g} / \mathrm{g})$. However, the variety of sugar cane of intermediary production cycle (16 months) used by those authors and the defoliation carried for removing all the dried leaves at the moment of sugar cane ensiling probably had an influence in the higher level of IVDDM in relation to the values observed in the present study. Furthermore, according to Fernandes et al. (2003), precocious varieties present higher levels of NDF, ADF, and lignin than the intermediary ones due to the rapid development of structures of sustentation that is represented by the polysaccharides of the vegetal cell wall.

The addition of urea in the ensilage increased $(\mathrm{P}<0.05)$ the nitrogenous level of the sugar cane silage with or without inoculate in relation to the control and was superior in IVDDM only for the silage with urea (without inoculate). The increase in the IVDDM was possible, probably because during the ensilage the urea, hydrolyzed by urease, it is transformed into $\mathrm{NH}_{3}$, which reacts with water to produce ammonium hydroxide (Sundstol \& Coxworth, 1984 cited by Siqueira et al., 2007), raising the concentration of $\mathrm{NH}_{3}-\mathrm{N}$, providing better ammonium ruminal fermentation and resulting in more elevated digestibility. On the other hand, only the elevation in the $\mathrm{N}$ level reported in the treatment silage with inoculate + urea was not enough to increase the IVDDM, what demonstrated the negative effect, for this parameter, when associating $L$. buchneri with urea.

Bovines presented higher IVDDM $(\mathrm{P}<0.05)$ in relation to bubaline for all treatments (Table 3 ). Such results may be related to the differences in the ruminal fauna and flora of these species. According to Franzolin \& Franzolin (2000), bubaline presented higher concentrations of ruminal fibrolytic and ciliated bacteria of the subfamily Diplodiniinae and Epidinium--classified as large protozoans with cellulolytic and hemicellulolytic activity that were adhered to the solid stages of the digesta. Moreover, according to Wanapat et al. (2000) and Franzolin \& Franzolin (2000), bubaline presented lower concentration of holotric ciliated protozoan (corresponding to $250 \mathrm{~g} / \mathrm{kg}$ of the total microbial mass) that ferments soluble carbohydrates and protein and are present in the liquid stage. Considering the in vitro methodology applied, which used only the liquid phase of the rumen with low concentration of microorganism, therefore with low metabolic activity (Czerkawski, 1986), it resulted in an underestimation of IVDDM, specially for buffaloes.

Those suppositions regarding the underestimation of IVDDM for bubaline species were enhanced by the in vivo digestibility assay carried by Maeda (2007), who did not observe difference in the total apparent digestibility of DM between bovine and bubaline (which presented the mean value of $0.558 \mathrm{~g} / \mathrm{g}$, which is close to the one reported for IVDDM in bovines $(0.561 \mathrm{~g} / \mathrm{g})$ when evaluating the sugar cane silages inoculated with L. buchneri + agroindustrial residuals (cassava byproduct meal and soybean hull)) and urea in a $60: 40 \%$ of roughage:concentrate ratio. The difference detected in the values of total digestibility of DM in the in vivo $(0.558 \mathrm{~g} / \mathrm{g})$ and in vitro $(0.398 \mathrm{~g} / \mathrm{g})$ assays for bubaline species signalize the need for correction of approximately $0.300 \mathrm{~g} / \mathrm{g}$ in the IVDDM when using the ruminal liquid of buffalos fed on diets based on sugar cane.

The mean values of $\mathrm{pH}$ of the sugar cane silages with addition were low and varied from 3.1 to 4.0 (Table 3). It is possible to observe that the lowest values of $\mathrm{pH}(\mathrm{P}<0.05)$ were for silage with inoculate and inoculate + cassava byproduct, which did not differ from the silage without the addition, followed by the silage with inoculate + soybean hulls. The highest value of $\mathrm{pH}(\mathrm{P}<0.05)$ was presented by the silage with inoculate + urea, followed by the one with urea only, which was already expected, since urea shows a buffering power. Neverheless, the $\mathrm{pH}$ was higher for treatment with inoculate + urea in relation to others that showed no difference in total DM losses and presented higher IVDDM than the other ones. This suggests the beneficial effect of nitrogen on digestibility and loss control (Table 3). Sousa et al. (2008) observed that addition of urea in sugar cane silage showed, by a buffer effect, higher $\mathrm{pH}$. The authors suggest that these results may explain, in part, the beneficial effects of nitrogen in controlling the production of ethanol, reducing losses of soluble carbohydrates and DM, and improving the IVDDM compared with the control silage. 
Although the yeast growth is not damaged when the $\mathrm{pH}$ is between 3.5 and 6.5 and some species are able to survive in pH under 2.0 (McDonald et al., 1991), according to Jobim \& Gonçalves (2003), a rapid pH drop (around 4.0), after fermentation, is important for avoiding the growth of the bacteria of the genus Clostridium and enterobacteria. However, a low final $\mathrm{pH}$ does not ensure the absence of the clostridia activity and the minimization of proteolysis. Sugar cane silage presents rapid decline of $\mathrm{pH}$ with values inferior to 4.0 on the third day of ensilage as observed by Pedroso et al. (2005).

No effect of the addition of additives $(\mathrm{P}>0.05)$ on the total losses of DM (plant respiration, fermentation, gases, and effluents) of the silages were observed. Silages presented average $78 \mathrm{~g} / \mathrm{kg}$. Rotz \& Muck (1994), in a simulation model of losses during ensilage, foresaw total losses of $177 \mathrm{~g} / \mathrm{kg}$ of DM for silages with production effluents. Such losses by effluents and gases are minor if considering the whole proof of confection use of the silage; the losses of major importance are related to the nutritive value of the forage. Still, Pedroso et al. (2007) also found similar values with chemical additives and microbial control of DM losses in the ensilage of sugar cane and found lower total DM losses with 10 and $15 \mathrm{~g} / \mathrm{kg}$ urea (70.8) and with addition of L . buchneri (80.5) compared with sodium benzoate, calcium propionate, potassium sorbate and L. plantarum added to silage, and control (182.0). Losses observed in present study were reduced due to the pattern of fermentation in laboratory silos and also achieved high specific mass $\left(600 \mathrm{~kg} / \mathrm{m}^{3}\right)$.

According to Jobim et al. (2007) low values of specific mass leads to higher porosity and air infiltration, reduced aerobic stability thus reducing the nutritive value of silage; it is recommended that it be between $550 \mathrm{~kg}$ to $850 \mathrm{~kg}$ of green mass $/ \mathrm{m}^{3}$. These losses may be, in most cases, underestimated in relation to the field situation due to greater control in the environment of the laboratory silo (Jobim et al., 2007).

The aerobic stability of the treated sugar cane silages was evaluated and it was considered as the time (hours) needed to elevate the temperature of the silage mass in $2^{\circ} \mathrm{C}$ in relation to the room temperature, which presented the mean of $18.4{ }^{\circ} \mathrm{C}$ and variation between 14 and $23^{\circ} \mathrm{C}$. The addition of the inoculate $L$. buchneri to the sugar cane silage increased the aerobic stability in 22 hours in relation to the control, 55 and 33 hours, respectively (Figures 1a and 1b). The warming of the ensiled mass, according to Rotz \& Muck (1994), is due to the action of the yeasts and acidacetic bacteria (anaerobic microorganisms) that consume soluble components such as sugars and the product of fermentation, potentially increasing the temperature of the silages.
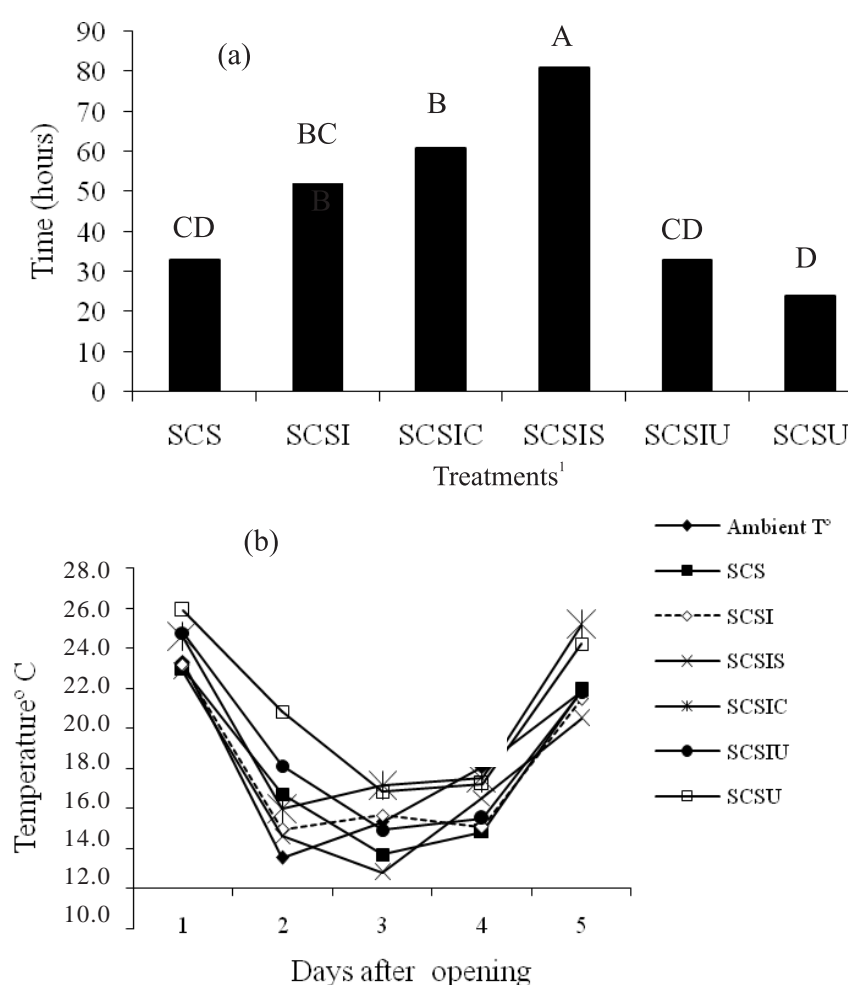

Figure 1 - Aerobic stability (hours) (a) and ambient and silage temperatures of sugar cane with different additives in function of the days after the opening (b); Sugar cane silage (SCS), sugar cane silage + urea (SCSU), sugar cane silage + inoculate (SCSI), SCSI+ urea (SCSIU), SCSI + cassava by product meal (SCSIC), SCSI + soybean hulls (SCSIS) capital letters differ in the columns; means compared between treatments $(\mathrm{P}<0.05)$.

Recent studied have shown that the use of L. buchneri in the silages increases the aerobic stability by reducing the growth and survival of the yeasts during the anaerobic conservation stage and after in the aerobiosis (Driehuis et al., 2001; Pedroso, et al., 2008; Siqueira et al., 2010). In the present study, the silage with inoculate solely confirmed the effect of $L$. buchneri - the increase in the anaerobic stability when compared with the control silage. Quite similar values were observed by Siqueira et al. (2007) for sugar cane silages ( 32 hours) and with L. buchneri (60 hours). According to Pedroso et al. (2008) the conversion of lactic acid into acetic acid by L.buchneri and the fungicide effect of acetic acid are probably the major reasons for stability improvement.

L. buchneri degrades under anaerobic conditions; lactic acid in acetic acid and 1,2-propanediol; the reduction of lactic acid represents a decrease of potentially fermentable substrate for yeast (Oude Elferink et al., 2001) and acid 1,2 - propanediol as a substrate for strains of Lactobacillus 
diolivorans sp. nov., transformed into 1-propanol and propionic acid (Krooneman et al., 2002) . According to Moon (1983) acetic acid in combination with propionic acid shows synergistic effect capable of reducing the growth of yeasts and fungi.

The use of urea in the sugar cane ensilage reduced 27\% of the aerobic stability in relation to the control, and inhibited the effect of L. buchneri, as observed in the silage with inoculate + urea, which presented the same stability as control: 33 hours. This inhibition was probably due to formation of ammonia inside the silo, because the ammonia presents inhibitory effect with microorganisms (Lopes \& Evangelista, 2010), which is already evident with yeast and may have reduced the growth of populations of heterofermentative lactic-acid bacteria, producing acetic and lactic acid. Pedroso et al. (2008) observed that the aerobic stability in sugar cane silage with addition of $10 \mathrm{~g} / \mathrm{kg}$ of urea did not differ from the control silage. However, $15 \mathrm{~g} / \mathrm{kg}$ of urea caused an increase of $11 \%$ in the aerobic stability.

Other factors may affect the aerobic stability, and according to McDonald et al. (1991), such factors would be the variation of the levels of DM, residual soluble carbohydrates, and the concentrations of the acetic and butyric acids in silages. Besides, they stress that the aerobic stability decreased with the increase of the nutritive value of the silage as observed for treatment with urea with less aerobic stability and higher values of IVDDM and nitrogenous levels in relation to control. The urea is converted into ammonia by the urease enzyme, which in contact with water forms ammonium hydroxide, which acts to solubilize fibrous fractions in addition to increasing the concentration of $\mathrm{NH}_{3}-\mathrm{N}$ in the silage (Siqueira et al., 2007) and consequently improving in digestibility.

The associative effect of $L$. buchneri with agroindustrial residuals conferred to treatments silage with cassava byproduct and silage with inoculate + soybean hulls increases in the aerobic stability of four and 24 percentage points, respectively, in relation to the silage with inoculate only, thus demonstrating a positive effect. Hence, Schmidt (2006) evaluated the doses of heterolatic bacteria L. buchneri on the aerobic stability of sugar cane silages with and without addition of concentrated ingredients to silages and observed that the increase of DM, with addition of concentrate, substantially increased the aerobic stability from 14.4 to 96.0 hours $\left(5 \times 10^{4} \mathrm{UFC} / \mathrm{g}\right.$ fresh forage $)$ and from 55.2 to 79.2 hours $\left(1 \times 10^{5} \mathrm{UFC} / \mathrm{g}\right.$ fresh forage). It is likely that the reduction in the water activity - due to the increase in the DM level - inhibited the microbial growth. Yeasts were more resistant to bacteria; they are inactivated when the water activity of the forage is less than 0.6 (McDonald et al., 1991), a fact that may have occurred for the silage with cassava byproduct and the one with inoculate + soybean hulls due to their higher levels of DM. In a review, Jobim et al (2007) observed that the development of bacteria and fungi is limited to values above 0.78 and 0.90 water activities. The increase in DM content causes higher osmotic pressure, making the environment unfavorable to the development or metabolic activity of yeast (Van Soest, 1994).

Interaction of the animal species and treatment $(\mathrm{P}<0.05)$ was reported only for the degradation rates of the fraction $\mathrm{b}$ (c) of DM of the sugar cane silages evaluated in the in situ assay (Table 4). The addition of cassava byproduct and soybean hull to the sugar cane silage containing L. buchneri increased the degradation rate of the roughage for bubaline; but for bovines it was not observed. These byproducts present high digestibility; however, for bovines, the degradation rate of the silage with cassava byproduct was $48.1 \%$ slower than the silage with inoculate - not presenting a chemical and/or biological explanation for this fact. Nevertheless, these results did not influence the ED of DM for this treatment, for the solid passage rate of $0.05 / \mathrm{h}$, which was superior to the others (Table 5) regardless of the species.

Bubaline presented higher values of degradation rates of the fraction $b$ (c) of the DM for the silage with cassava and that with inoculate + soybean hulls $(\mathrm{P}<0.05)$ in relation to bovines, which reduced the time of degradation of the fraction $b$ in $56.3 \%$ and $29.4 \%$, respectively. Bhatia et al. (1995) reported higher degradation rates of the fractions $b$ for bubaline $(0.0373 / \mathrm{h})$ in relation to bovines $(0.0254 / \mathrm{h})$ for ten feeds of different nutritional values (from 20 to $160 \mathrm{~g} / \mathrm{kg}$ of crude protein). Ichinohe et al. (2004) also observed higher values $(\mathrm{P}<0.05)$ for bubaline $(0.037 / \mathrm{h})$ in relation to

Table 4 - Degradation rate of fraction b (c,/h) of DM of sugar cane silages with different additives in bovine and buffaloes

\begin{tabular}{|c|c|c|c|c|c|c|}
\hline \multirow[b]{3}{*}{$\mathrm{DM}$} & Treatment $^{1}$ & SCSI & SCSIC & SCSIS & SCSIU & $\mathrm{CV} \%$ \\
\hline & Species & \multicolumn{5}{|c|}{ Degradation rate of the fraction b (c) } \\
\hline & Bovine & $0.027 \mathrm{~A}$ & $0.014 \mathrm{Bb}$ & $0.024 \mathrm{ABb}$ & $0.023 \mathrm{AB}$ & 22.22 \\
\hline & Buffaloes & $0.020 \mathrm{C}$ & $0.032 \mathrm{Aa}$ & $0.034 \mathrm{Aa}$ & $0.022 \mathrm{BC}$ & \\
\hline
\end{tabular}

${ }^{1}$ SCSI = sugar cane silage + inoculate, SCSIC = SCSI + cassava by product meal, SCSIS = SCSI + soybean hulls, SCSIU = SCSI + urea.

Capital letters compared means within a row between experimental diets and small letters compared means within a column between species. Means followed by different letters differ by Tukey test $(\mathrm{P}<0.05)$. $\mathrm{CV}=$ coefficient of variation. 
Table 5 - Estimation of kinetic parameters effective degradability of neutral detergent fiber (NDF) of sugar cane silages with different additives in bovine and buffaloes

\begin{tabular}{|c|c|c|c|c|c|}
\hline Bovine & $\mathrm{U}(\mathrm{g} / \mathrm{kg})$ & I g/kg & $c\left(\mathrm{~h}^{-1}\right)$ & $p\left(\mathrm{~h}^{-1}\right)$ & $\lambda\left(\mathrm{h}^{-1}\right)$ \\
\hline SCSI & 347.5 & 513 & 0.0413 & 0.103 & - \\
\hline SCSIC & 351.3 & 525.0 & - & - & 0.041 \\
\hline SCSIS & 535.7 & 341.7 & 0.045 & 0.056 & - \\
\hline SCSIU & 357.2 & 494.7 & - & - & 0.048 \\
\hline Buffaloes & $\mathrm{U}(\mathrm{g} / \mathrm{kg})$ & I g/kg & $c\left(\mathrm{~h}^{-1}\right)$ & $p\left(\mathrm{~h}^{-1}\right)$ & $\lambda\left(\mathrm{h}^{-1}\right)$ \\
\hline SCSI & 379.0 & 529.0 & 0.031 & 0.088 & \\
\hline SCSIC & 410.2 & 489.2 & 0.023 & 0.415 & \\
\hline SCSIS & 517.5 & 356.2 & - & - & 0.068 \\
\hline SCSIU & 423.9 & 481.6 & 0.031 & 0.109 & \\
\hline
\end{tabular}

$\mathrm{U}=$ insoluble but potentially degradable fraction of NDF; $\mathrm{I}=$ undegradable fraction of NDF; $\mathrm{c}=$ rate of degradation of potentially degradable NDF fraction $\left(\mathrm{h}^{-1}\right)$; $\mathrm{p}=$ fractional rate of latency $\left(\mathrm{h}^{-1}\right) ; \lambda=$ degradation rate $\left(\mathrm{h}^{-1}\right)$ when $p$ tends to $c$.

bovines $(0.026 / \mathrm{h})$ for the degradation rate of DM of corn silage.

Franzolin \& Dehority (1999) observed higher degradation levels of the fractions $b$ (c) of roughage feeds for bubaline in relation to bovines for DM $(0.049 / \mathrm{h}$ vs. 0.038/h) and $\operatorname{ADF}(0.052 / \mathrm{h}$ vs. 0.042/h), respectively. The authors conclude that the microbial population that lives in the rumen of the bubaline seems to be more efficient in the colonization of vegetal cells and may degrade more rapidly the feed fractions. However, in the present study, higher degradation rate of the fraction $b$ for buffaloes was observed only for silage with cassava and silage with inoculate + soybean hulls in relation to bovines; silages with inoculate and inoculate + urea presented similar values of degradation.

There was higher insoluble and potentially degradable (U) fraction of the NDF for the silage with inoculate in bovines and buffaloes (Table 5). The superiority of the sugar cane silage with addition of soybean hull is related to the composition of the fraction of the cell wall of the soybean that presents high digestibility (Van Soest, 1994). With regard to the species, Franzolin \& Franzolin (2000) did not observe any difference for the fraction (U) of NDF between bovines and bubaline fed on in natura sugar cane and observed means of $544.8 \mathrm{~g} / \mathrm{kg}$.

The treatments presented difference with regard to the degradation rate of the fraction U (c) of the NDF; degradation of the silage with inoculate + cassava byproduct was slower in relation to the silage with inoculate + soybean hulls in $27 \%$ for bovine and $66 \%$ for buffaloes; intermediary values were observed for the silage with inoculate and inoculate + urea, which did not present any difference from the others. The addition of soybean hull increased the degradation rate of the NDF while the addition of cassava byproduct meal reduced this rate probably because of the carbohydrates present in the residuals that interfered in the results. Soybean hull presents high level of digestible NDF (high level of pectin) and its fermentation in the rumen does not produce lactic acid (Hatfield \& Wiemer, 1995, cited by Nussio et al., 2006), making the maintenance of the ruminal $\mathrm{pH}$ easy, which could provide a more suitable environment for cellulolytic microorganisms. On the other hand, the cassava byproduct meal with high level of starch and high ruminal degradation (Zeoula \& Caldas Neto, 2001) may produce ruminal $\mathrm{pH}$, which is harmful to cellulolytic bacteria.

The highest fraction $a$ solution of DM - regardless of the species - was for the silage control + inoculate + cassava byproduct $(\mathrm{P}<0.05)$ in relation to silages with inoculate, inoculate + soybean hulls and inoculate + urea, which did not present differences (Table 6). The smallest level of NDF and consequently higher level of non-fibrous carbohydrates was present in the treatment with inoculate + cassava byproduct (Table 1). Cassava is characterized by having high levels of non-structural carbohydrates, especially starch.

The silage with inoculate + soybean hulls presented higher $(\mathrm{P}<0.05)$ fraction of degradation $b$ of $\mathrm{DM}$ in relation to the other treatments, which did not show any difference. In an assay of in situ degradation of the DM of sugar cane silage with citric pulp, Silveira et al. (2002) observed values close to the ones of the present research for fraction $b$ (40.83 g/100 g).

The increases in the level of DM provided by the agroindustrial byproducts resulted in higher potential and effective degradability of DM $(0.02 / \mathrm{h})$ for inoculate + cassava byproduct and inoculate + soybean hulls in relation to inoculate only and inoculate + urea. With regard to the solid passage rate $(0.05 / \mathrm{h})$, there was higher effective degradability of DM $(\mathrm{P}<0.05)$ for inoculate + cassava byproduct, followed by inoculate + soybean hulls and lower values for treatment with inoculate only and inoculate + urea. The lowest levels of NDF and ADF of silage control + inoculate + cassava byproduct (Table 1 ) and the highest level of NFC provided by the level of starch $(824 \mathrm{~g} / \mathrm{kg})$ 
Table 6 - Soluble fraction $a$ and degradable potential $b$, degradation rate of the fraction $b$ (c), potential degradability (PD) of dry matter (DM) and effective degradability (ED) of DM and NDF of sugar cane silages with different additives for the passage rates of 0.02 and $0.05 / \mathrm{h}$ in bovines and buffaloes

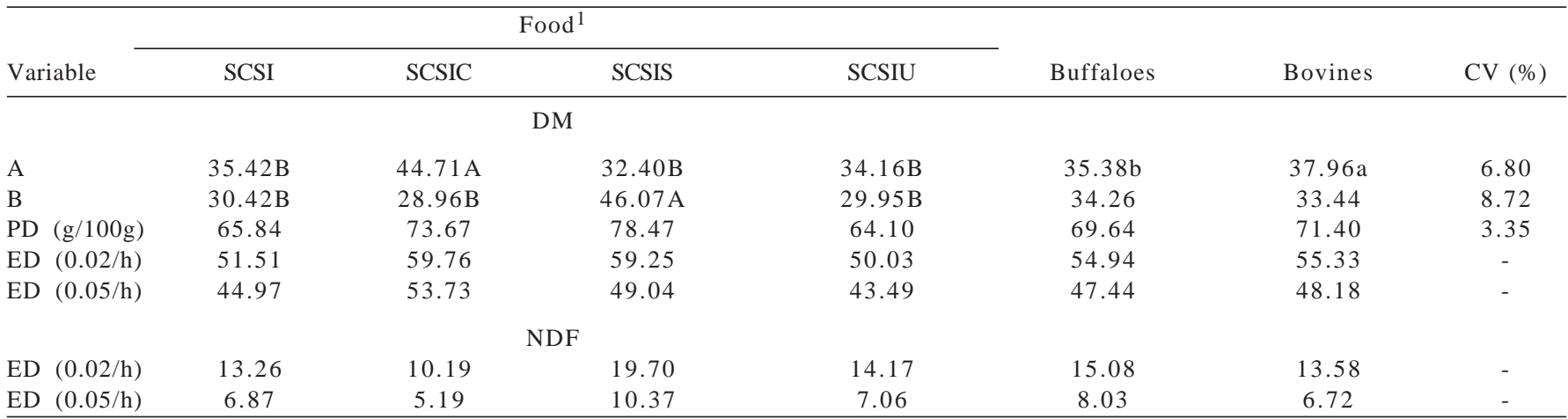

${ }^{1}$ SCSI = sugar cane silage + inoculate SCSIC = SCSI + cassava byproduct; SCSIS = SCSI + soybean hull; SCSIU = SCSI + urea.

Uppercase letters compare the means in the rows between the experimental diets, and the lowercase letters compare the means in the rows between the species. Means followed by different letters differ by the test of Tukey $(\mathrm{P}<0.05)$. CV $=$ coefficient of variation.

present in the cassava byproduct meal (Zeoula \& Caldas Neto, 2001) may have contributed to such results, which are close to those observed in IVDDM for treatment with inoculate + cassava byproduct (0.543), which was superior to silage with inoculate only (0.413).

Thus, in both assays (in situ and in vitro), the silage with inoculate and silage with inoculate + urea that presented higher levels of lignin and silica (Table 3) also presented lower values of digestibility of DM. Similarly, in the study of in vivo digestibility, there was higher total digestibility of DM for the silage with inoculate + soybean hulls in relation to the other diets (Maeda, 2007).

The addition of urea did not cause differences in ED of DM between silages with inoculate and inoculate + urea as observed in the different passage rates. For $0.05 / \mathrm{h}$, the values observed for ED of DM were $43.49 \mathrm{~g} / 100 \mathrm{~g} v s$. $44.97 \mathrm{~g} / 100 \mathrm{~g}$ for inoculate and inoculate + urea. These results are close to those observed by Schmidt et al. (2007) - 44.3 g/100 g vs. 49.2 g/100 g - for sugar cane silage treated with Lactobacillus buchneri and for sugar cane silages with addition of $0.5 \%$ of urea in the fresh forage - which did not show any difference.

Higher values ED of NDF (concerning the passage rate of 0.02 and $0.05 / \mathrm{h}$ ) were observed for treatment with inoculate + soybean hulls in relation to the other treatments. The ensilage with foods that contain pectin - such as citric pulp and soybean hull - proportionate high degradation of NDF probably because of the high nutritional value of the pectin, which is completely fermented in the rumen with high fermentation rate (Van Soest, 1994).

\section{Conclusions}

The addition of Lactobacillus Buchneri to the sugar cane silage increases the aerobic stability and the addition of urea to the sugar cane silage increases the in vitro digestibility of the DM. However, there is no positive synergism in the association of Lactobacillus Buchneri and urea to the sugar cane silage. The addition of agroindustrial byproducts (soybean hull and cassava byproduct) in sugar cane ensilages with $L$. buchneri increases the nutritional value of this roughage, regardless of the species - bovines or buffaloes.

\section{References}

AGRICULTURAL AND FOOD RESEARCH COUNCIL - AFRC. Energy and protein requeriment of ruminants. Wallingford: CAB international, 1993. 159p.

BAUMGARDT, B.R.; TAYLOR, M.W.; CASON, J.L. Evaluation of forages in the laboratory. II. Simplified artificial rumen procedure for obtaining repeatable estimates of forage nutritive value. Journal of Dairy Science, v.45, n.1, p.62-68, 1962.

BHATIA, S.K.; SANGWAN, D.C.; PRADHAN, K. et al. Ruminal degradation of fibrous components of various feens in cattle and buffalo. Indian Journal of animal Siences, v.65, n.2, p.208-212, 1995.

CZERKAWSKI, J.W. An introduction to rumen studies. Great Britain: A. Wheaton \& Co. Ltd, Exeter, 1986. 236p.

DRIEHUIS, F.; OUDE ELFERINK, S.J.W.H.; VAN WILKSELAAR, P.G. Fermentation characteristics and aerobic stability of grass silage inoculated with Lactobacillus buchneri, with or without homofermentative lactic acid bacteria. Grass and Forage Science, v.56, n.4, p.330-343, 2001.

FERNANDES, A.M.; QUEIROZ, A.C.; PEREIRA, J.C. et al. Composição químico-bromatológica de cana-de-açúcar (Saccharum spp L.) com diferentes ciclos de produção (precoce e intermediário) em três idades de corte. Revista Brasileira de Zootecnia, v.32, n.4, p.977-985, 2003.

FRANZOLIN, R.; DEHORITY, B.A. Comparison of protozoal population and digestion rates between water buffalo and cattle fed an all forage diet. Journal of Applied Animal Research, v.16, n.1, p.33-46, 1999.

FRANZOLIN, R.; FRANZOLIN, M.H.T. Efeitos de dietas com polpa cítrica em substituição ao milho em grão no concentrado sobre a degradabilidade e a fauna ruminal em bubalinos. Revista Brasileira de Zootecnia, v.29, n.6, p.2109-2118, 2000.

FREITAS, A.W.P.; PEREIRA, J.C.; ROCHA, F.C. et al. Avaliação da qualidade nutricional da silagem de cana-de-açúcar com 
aditivos microbianos e enriquecida com resíduo da colheita de soja. Revista Brasileira de Zootecnia, v.35, n.1, p.38-47, 2006.

ICHINOHE, T.; ORDEN, E.A.; DEL BARRIO, A.N. et al. Comparison of voluntary feed intake, rumen passage and degradation kinetics between crossbred Brahmam cattle (Bos indicus) and swamp buffaloes (Bubalus bubalis) fed a fattening diet based on corn silage. Animal Science Journal, v.75, n.6, p.533-540, 2004

JOBIM, C.C.; GONÇALVES, G.D. Microbiologia de forragens conservadas. In: REIS, R.A.; BERNARDES, T.F.; SIQUEIRA, G.R. et al. (Eds.). Volumosos na produção de ruminantes: valor alimentício de forragens. Jaboticabal: Funep, 2003. p.1-26.

JOBIM, C.C.; NUSSIO, L.G.; REIS, R.A. Avanços metodológicos na avaliação da qualidade da forragem conservada. Revista Brasileira de Zootecnia, v.36, p.101-119, 2007 (supl. especial).

KROONEMAN, J.; FABER, F.; ALDERKAMP, A. Lactobacillus diolivorans sp. nov., a 1,2-propanediol degrading bacterium isolated from aerobically stable maize silage. International Journal of Systematic and Evolutionary Microbiology, v.52, p.639-646, 2002.

KUNG JR., L.; ROBINSON, J.R.; RANJIT, N.K. et al. Microbial populations, fermentation end-products, and aerobic stability of corn silage treated with ammonia or a propionic acid-based preservative. Journal of Dairy Science, v.83, n.3, p.1479-1486, 2000.

LICITRA， G.; HERNANDEZ， T.M.; VAN SOEST, P.J. Standardization of procedures for nitrogen fractionation of ruminant feeds. Animal Feed Science and Technology, v.57, n.4, p.347-358, 1996.

LIMA, J.A.; EVANGELISTA, A.R.; ABREU, J.G. et al. Silagem de cana-de-açúcar (Saccharum officinarum L.) enriquecida com uréia ou farelo de soja (compact disc). In: REUNIÃO DA SOCIEDADE BRASILEIRA DE ZOOTECNIA, 39., 2002, Recife. Anais... Recife: SBZ, 2002. (CD-ROM).

LOPES, J.; EVANGELISTA, A. R. Características bromatológicas, fermentativas e população de leveduras de silagens de cana-deaçúcar acrescidas de ureia e aditivos absorventes de umidade. Revista Brasileira de Zootecnia, v.39, n.5, p.984-991, 2010

MAEDA, E.M. Caracterização química, digestibilidade e degradabilidade da silagem de cana-de-açúcar com diferentes aditivos em bovinos e bubalinos. 2007. $111 \mathrm{f}$. Tese (Doutorado em Zootecnia) - Universidade Estadual de Maringá, Maringá.

MENDES, C.Q.; SUSIN, I.; NUSSIO, L.G. et al. Efeito do Lactobacillus buchneri na fermentação, estabilidade aeróbia e no valor nutritivo de silagem de cana-de-açúcar. Revista Brasileira Zootecnia, v.37, n.12, p.2191-2198, 2008

McDONALD, P.; HENDERSON, A.R.; HERON, S.J.E. The biochemistry of silage. 2.ed. Merlow: Chalcomb Publications, 1991. 340p

MEHREZ, A.Z.; ORSKOV, E.R. A study of the artificial fiber bag technique for determining the digestibility of feeds in the rumen. Journal of Agricultural Science, v.88, n.3, p.645-650, 1977.

MOLINA, L.R.; FERREIRA, D.A.; GONÇALVES, L.C. et al. Padrão de fermentação da silagem de cana-de-açúcar (Saccharum officinarum L.) submetida a diferentes tratamentos (compact disc). In: REUNIÃO DA SOCIEDADE BRASILEIRA DE ZOOTECNIA, 39., 2002, Recife. Anais... Recife: SBZ, 2002. (CD-ROM).

MOON, N.J. Inhibition of the growth of acid tolerant yeasts by acetate, lactate and propionate and their synergistic mixtures. Journal of Applied Bacteriology, v.55, p.453-460, 1983.

NATIONAL RESEARCH COUNCIL - NRC. Nutrient requeriments of beef cattle, Washington, D.C.: National Academy Press, 1996. 242p.

NUSSIO, L.G.; SCHMIDT, P. Tecnologia de produção e valor alimentício de silagens de cana-de-açúcar. In: SIMPÓSIO SOBRE PRODUÇÃO E UTILIZAÇÃO DE FORRAGENS CONSERVADAS, 2., Maringá, 2004. Anais... Maringá: 2004. p.1-33.
NUSSIO, L.G.; CAMPOS, F.P.; LIMA, M.L.M. Metabolismo de carboidratos estruturais. In: BERCHIELLI, T.T.; PIRES, A.V.; OLIVEIRA, S.G. (Orgs.). Nutrição de ruminantes. Jaboticabal: Funep, 2006. p.183-228.

OUDE ELFERINK, S.J.W.H.; KROONEMAN, J.; GOTTSCHAL, J.C. et al. Anaerobic conversion of lactic acid to acetic acid and 1,2 propanediol by Lactobacillus buchneri. Applied Environmental Microbiology, v.67, p.125-132, 2001.

ORSKOV, E.R.; MCDONALD, I. The estimation of protein degradability in the rumen from incubation measurements weighted according to rate of passage. Journal of Agricultural Science, v.92, n.2, p.499-503, 1979.

PEDROSO, A.F; NUSSIO, L.G.; LOURES, D.R.S. et al. Efeito do tratamento com aditivos químicos e inoculantes bacterianos nas perdas e na qualidade de silagens de cana-de-açúcar. Revista Brasileira de Zootecnia, v.36, n.3, p.558-564, 2007.

PEDROSO, A.F.; NUSSIO, L.G.; LOURES, D.R.S. et al. Fermentation, losses, and aerobic stability of sugarcane silages treated with chemical or bacterial additives. Scientia Agricola, v.65, p.589-594, 2008.

PEDROSO, A.F.; NUSSIO, L.G.; PAZIANI, S.F. et al. Fermentation and epiphytic microflora dynamics in sugar cane silage. Scientia Agricola, v.62, n.5, p.427-432, 2005.

RIBEIRO, L.S.O.; PIRES, A.J.V.; CARVALHO, G.G.P.Composição química e perdas fermentativas de silagem de cana-de-açúcar tratada com ureia ou hidróxido de sódio Revista Brasileira de Zootecnia, v.39, n.9, p.1911-1918, 2010.

ROTZ, C.A.; MUCK, R.E. Changes in forage quality during harvest and storage. In: FAHEY JUNIOR, G.C. (Ed.) Forage quality, evaluation and utilization. Madison: American Society of Agronomy, 1994. p.828-868.

SCHMIDT, P. Perdas fermentativas na ensilagem, parâmetros digestivos e desempenho de bovinos de corte alimentados com rações contendo silagens de cana-de-açúcar. 2006 228f. Tese (Doutorado em Agronomia) - Escola Superior de Agricultura Luiz de Queiroz, Piracicaba.

SCHMIDT, P.; NUSSIO, L.G.; RIBEIRO, J.L. et al. Aditivos químicos ou biológicos na ensilagem de cana-de-açúcar. 2. Parâmetros ruminais e degradabilidade da matéria seca e das frações fibrosas. Revista Brasileira de Zootecnia, v.36, n.5, p.1676-1684, 2007.

SILVA, D.J.; QUEIROZ, A.C. Análise de alimentos (Métodos químicos e biológicos). 3.ed. Viçosa, MG: UFV, 2002. 235p.

SILVEIRA, R.N.; BERCHIELLI, T.T.; FREITAS, D. et al. Fermentação e degradabilidade ruminal em bovinos alimentados com resíduos de mandioca e cana-de-açúcar ensilados com polpa cítrica peletizada. Revista Brasileira de Zootecnia, v.31, n.2, p.793-891, 2002.

SIQUEIRA, G.R; REIS, R.A.; SCHOCKEN-ITURRINO, R.P. et al. Perdas de silagens de cana-de-açúcar tratadas com aditivos químicos e bacterianos Revista Brasileira de Zootecnia, v.36, n.6, p.2000-2009, 2007 (supl.).

SIQUEIRA, G.R; REIS, R.A.; SCHOCKEN-ITURRINO, R.P. et al. Queima e aditivos químicos e bacterianos na ensilagem de cana-de-açúcar. Revista Brasileira de Zootecnia, v.39, n.1, p.103-112, 2010.

SNIFFEN, C.J.; O’CONNOR, J.D.; Van SOEST, P.J. et al. A net carbohydrate and protein system for evaluating cattle diets: II. Carbohydrate and protein avaiability. Journal of Animal Science, v.70, n.10, p.3562-3577, 1992.

SOUSA, D.P.; MATTOS, W.R.S.; NUSSIO, L.G. et al. Efeito de aditivo químico e inoculantes microbianos na fermentação e no controle da produção de álcool em silagens de cana-de-açúcar Revista Brasileira de Zootecnia, v.37, n.9, p.1564-1572, 2008.

STATISTICAL ANALYSES SYSTEM - SAS. User's guide statistics, versão 6.12. Cary: SAS Institute, 1997. 1167p.

THIAGO, L.R.L.S.; VIEIRA, J.M. Cana-de-açúcar: uma alternativa de alimento para a seca. Available at: <http://www.cnpgc.embrapa.br/ publicacoes/cot/COT73.html>. Accessed on: Aug. 29, 2006. 
UNIVERSIDADE FEDERAL DE VIÇOSA - UFV. SAEG - Sistema de análises estatísticas e genéticas (Manual do usuário). Versão 7.1. Viçosa, MG. 1997. 150p.

VAN MILGEN, J.; MURPHY, M.R.; BERGER, L.L. A compartmental model to analyze ruminal digestion. Journal of Dairy Science, v.74, n.8, p.2515-2529, 1991.

VAN SOEST, P.J. Nutritional ecology of the ruminant. 2.ed. London: Comstock Publishing Associates, 1994. 476p.

VAN SOEST, P.J.; JONES, L.H.P. Effect of silica in forage upon digestibility. Journal of Dairy Science, v.51, n.10, p.1644-48, 1968.

VAN SOEST, P.J.; WINE, R.H. The determination of lignin and cellulose in acid-detergent fibre with permanganate. Journal of the Association of Official Analytical Chemists, v.51, p.780-785, 1968.

VAN SOEST, P.J.; ROBERTSON, J.B.; LEWIS, B.A. Methods for dietary fiber, neutral detergent fiber, and nonstarch polysaccharides in relation to animal nutrition. Journal of Dairy Science, v.74, n.12, p.3583-3597, 1991.
VIEIRA, R.A.M.; PEREIRA, J.C.; MALAFAIA, P.A.M. et al. The influence elephant-grass (Pennisetum purpureum Schum., Mineiro variety) growth on the nutrient kinetic in the rumen. Animal Feed Science and Technology, v.67, p.151-161, 1997.

WANAPAT, M.; NGARMSANG, A.; KORKHUNTOT, S. et al. A comparative study on the rumen microbial population of cattle and swamp buffalo raised under traditional village conditions in the northeast of Thailand. Asian-Australasian Journal of Animal Sciences, v.13, n.7, p.918-921, 2000.

ZAMBOM, M.A.; SANTOS, G.T.; MODESTO, E.C. et al. Valor nutricional da casca do grão de soja, farelo de soja, milho moído e farelo de trigo para bovinos. Acta Scientiarum. Animal Sciences, v.23, n.4, p.937-943, 2001.

ZEOULA, L.M.; CALDAS NETO, S.F. Recentes avanços em amido na nutrição de vacas leiteiras. In: SIMPÓSIO INTERNACIONAL EM BOVINOCUlTURA DE LEITE, 2001, Lavras. Anais.. Lavras: UFLA-FAEPE, 2001. p.249-284. 